\title{
Redescription of Echinuria hypognatha Wehr, 1937 (Nematoda; Acuariidae) including ecology and new hosts
}

\author{
K. M. KAVETSKA ${ }^{1}$, A. STAPF ${ }^{1}$, K. KRÓLACZYK ${ }^{1}$, E. KALISIŃSKA ${ }^{2}$
}

\begin{abstract}
${ }^{1}$ Laboratory of Biology and Ecology of Parasites, West Pomeranian University of Technology, Judyma Str. 20, 71-466 Szczecin, E-mail: katarzyna.kavetska@zut.edu.pl; ${ }^{2}$ Department of Biology and Medical Parasitology, Pomeranian Medical University, Powstańców Wielkopolskich Av. 72, 70-111 Szczecin, Poland, E-mail: ekalist@pum.edu.pl
\end{abstract}

\begin{abstract}
Summary
Reports on the presence of Echinuria hypognatha Wehr, 1937 in Europe have so far provided only general information, and therefore we present further morphometric and ecological characteristics of this parasite. In this study, the examined nematodes were isolated from the digestive tract of 1005 wild ducks, representing 17 species from the northwestern Poland. The anatomical features of the parasite were in principle consistent with the description of the species by its discoverer and reports in the available literature. Nematodes (505 individuals) were found in $2.5 \%$ of the examined ducks, in five species wintering in Poland: Clangula hyemalis, Melanitta nigra, M. fusca, Mergellus albellus and Aythya fuligula. The exclusive locations of the nematode were the glands in the proventriculus. The highest incidence was recorded in Melanitta ducks, and the presence of this nematode only in birds wintering in Poland indicates that E. hypognatha is brought to Poland by birds migrating from the areas of Eastern Siberia.
\end{abstract}

Keywords: Nematoda; Echinuria hypognatha Wehr, 1937; Anatinae; Poland

\section{Introduction}

Nematodes of the genus Echinuria Soloviev, 1912 (Acuariidae) live in the glandular stomach of birds, although stronger invasions may also affect the esophagus and gizzard (Kavetska 2006, 2008). Characteristic features of these parasites are: the presence of cuticular cordons extending from the base of both labia; rows of spines running along the sides of the nematode (Skryabin et al., 1965; Baruš et al., 1978; Smogorzewska 1990); the presence of two spicules with unequal length and different shape in males; and 4 precloacal glands and 4-5 postcloacal glands in males (Smogorzewska 1990). The nematodes reported in birds living in aquatic environments: Anseriformes, Ciconiiformes, Lariformes, Charadriiformes and Phoeni- copteriformes (Skryabin et al., 1965; Baruš et al., 1978; Smogorzewska 1990, Pojmańska 2007, Kavetska 2006, 2008, Carreno 2008).

Genus Echinuria includes 15 species (Skryabin et al., 1965; Baruš et al., 1978; Smogorzewska 1990), five of which are observed in Europe: E. borealis Mawson, 1956, E. uncinata Rudolph, 1819, E. heterobrachiata Wehr, 1937, E. pamirica Ryzhikov \& Borgarenko, 1965, and E. Skryabiniensis Efimov, 1949. The presence of another nematode species in the European fauna, E. hypognatha Wehr, 1937, has been reported in our previous studies (Kavetska 2006, 2008). The species was first described in 1937 by Wehr, isolated from the Melanitta fusca deglandi living in the Smithsonian National Zoological Park in Washington (Skryabin et al., 1965). Subsequent reports (Skryabin et al. 1965; Baruš et al., 1978; Smogorzewska 1990) indicate the presence of the parasite in eider, spectacled eider, king eider, and scaup from north-east Asia (Kamchatka, Chukotka and western Yakutia). According to Skryabin et al (1965), the distinguishing feature of the parasite species is primarily the shape and form of the distal part of the longer spicule which is divided into three branches arranged in various configurations. The intermediate host of the parasite is not known.

Due to the lack of a current and complete description of the nematode E. hypognatha, the aim of this paper is a morphological and ecological redescription of this species obtained from wild Anatinae found in northwestern Poland.

\section{Material and methods}

The material consisted of nematodes isolated from the digestive tract of 1005 wild ducks (Anseriformes: Anatidae) from north-western Poland. Host species were represented by 17 species from eight genera belonging to three different ecological tribes: Anatini $(n=225)$, Aythyini $(n=$ 
413) and Mergini $(n=367)$. This study, conducted over the years 1999 - 2009, included gamebirds (according to Polish law: mallard, teal, tufted duck, and pochard, a total of 471 individuals) and protected birds (the remaining duck species, including 534 birds). All birds (except wild game mallards) were obtained dead from fishing nets. Isolated nematodes were fixed and stored in $70 \%$ ethanol, and X-rayed in glycerol or $80 \%$ lactic acid. The parasites were measured using a micrometer eyepiece, and the determinations were based on characteristic morphological and anatomical features using a Zeiss light microscope, based on the descriptions available in literature. The analysis of the quantitative structure was performed using the following parameters: extensiveness, intensity, relative density, and dominance index (Pojmańska 1993; Kavetska 2006, 2008).

\section{Results and Discussion}

\section{Morphology}

According to the first description by Wehr in 1937 (In: Skryabin et al., 1965) E. hypognatha has a cuticle with transverse striations and four sublateral rows of spikes running towards the rear end of the body. In a male, spikes begin close to the anterior end of the body and finish about
$1 \mathrm{~mm}$ from the posterior end. Winding cuticular cordons end in the glandular part of the pharynx, and at their end they are located slightly ventrally. The rear end of a male $E$. hypognatha is curved to the ventral side, with two pairs of precloacal glands and five postcloacal glands. Spicules are different in length, the left one splits into three unequal parts. A similar description of the species is given in unpublished materials by Ryzhikov (In: Skryabin et al. 1965), based on material isolated from the eider, spectacled eider, king eider and scaup from Kamchatka and Chukotka. The report describes that the nematode's body is short with four rows of sub-laterally located spines from the anterior to the posterior end of the body. The mouth is surrounded by two labia, from which four cordons run along both body sides. In the male, the end of the tail is curved to the ventral side. At the tail, in the area of the anus, there are 4 pairs of precloacal and 5 pairs of postcloacal papillae. The longer cylindrical spicule is partly massive and wide, and then in the distal end divided into three branches covered by a cuticular membrane.

Echinuria hypognatha, isolated from ducks wintering in Poland, is a parasite with a white body color, but when embedded in the pores of the glandular stomach wall, it assumes the color of the stomach mucous secretions. The nematodes are relatively small; a male body length ranges

Table 1. Main morphological features and measurements of E. hypognatha Wehr, 1937, as given by different authors ( $\mu \mathrm{m})$

\begin{tabular}{|c|c|c|c|c|c|c|}
\hline \multirow{2}{*}{ Parameter } & \multicolumn{2}{|c|}{ Wehr, 1937* } & \multicolumn{2}{|c|}{ Ryjikov (manuscript)* } & \multicolumn{2}{|c|}{ Own material } \\
\hline & male & female & male & female & male & female \\
\hline Total lenght & 4600 & 4100 & $2880-4400$ & $2880-4640$ & $\begin{array}{c}4761 \\
(4266-5040)\end{array}$ & $\begin{array}{c}5223.6 \\
(3960-6084)\end{array}$ \\
\hline Maximum width & 255.0 & $195.0-210.0$ & $176.0-192.0$ & $222.0-304.0$ & $\begin{array}{c}229.25 \\
(200.0-257.5)\end{array}$ & $\begin{array}{c}268.0 \\
(240.0-290.0)\end{array}$ \\
\hline $\begin{array}{l}\text { Lenght of buccal } \\
\text { capsule }\end{array}$ & $138.0-140.0$ & 147.0 & $96.0-144.0$ & $140.0-185.0$ & $\begin{array}{c}105 \\
(100.0-115.0)\end{array}$ & $\begin{array}{c}121.0 \\
(115.0-125.0)\end{array}$ \\
\hline Lenght of cordons & $975.0-1100$ & 1200 & $832.0-960.0$ & $1008-1280$ & $\begin{array}{c}1080 \\
(950.0-1250.0)\end{array}$ & $\begin{array}{c}1283.7 \\
(900.0-1548)\end{array}$ \\
\hline $\begin{array}{l}\text { Lenght of } \\
\text { oesophagus }\end{array}$ & & & & & $\begin{array}{c}1574.2 \\
(1390-1725)\end{array}$ & $\begin{array}{c}1657.9 \\
(1530-1875)\end{array}$ \\
\hline $\begin{array}{l}\text { Length of muscular } \\
\text { oesophagus }\end{array}$ & 321.0 & $255.0-328.0$ & $180.0-304.0$ & $247.0-330.0$ & $\begin{array}{c}338.5 \\
(310.0-375.0)\end{array}$ & $\begin{array}{c}357.0 \\
(300.0-400.0)\end{array}$ \\
\hline $\begin{array}{l}\text { Length of glandular } \\
\text { oesophagus }\end{array}$ & $1210-1460$ & $1000-1.200$ & $530.0-1200$ & $992.0-1200$ & $\begin{array}{c}1235.7 \\
(1050-1385)\end{array}$ & $\begin{array}{c}1300.9 \\
(1155-1500)\end{array}$ \\
\hline Lenght of tail & 185.0 & 147.0 & $160.0-240.0$ & $90.0-132.0$ & $\begin{array}{c}223.5 \\
(200.0-250.0)\end{array}$ & $\begin{array}{c}169.0 \\
(150.0-200.0)\end{array}$ \\
\hline $\begin{array}{l}\text { Vulva distance } \\
\text { from posterior end }\end{array}$ & & 839.0 & & $480.0-1008$ & & $\begin{array}{c}1097.7 \\
(810.0-1296)\end{array}$ \\
\hline $\begin{array}{l}\text { Length of left } \\
\text { spicule }\end{array}$ & $700.0-730.0$ & & $528.0-730.0$ & & $\begin{array}{c}674.5 \\
(600.0-750.0)\end{array}$ & \\
\hline $\begin{array}{l}\text { Length of right } \\
\text { spicule }\end{array}$ & 200.0 & & $149.0-185.0$ & & $\begin{array}{c}196.0 \\
(185.0-200.0)\end{array}$ & \\
\hline
\end{tabular}

*From Skryabin et al., 1965 
from 4.3 to $5.0 \mathrm{~mm}$, and a female from 3.9 to $6 \mathrm{~mm}$ (Table 1). The anterior end of the body with the cuticle with transverse striations is the same in both sexes (Fig. 1). Clearly visible on the sides of the mouth are two small labia, and from their base run two pairs of long cuticular cordons on the sides of the body. In males and females they converge (and end at the same point) at about $1 / 5$ and $1 / 4$ body length (males and females, respectively). In this section of the body four sub-lateral rows of spines also begin, directed towards the posterior end, the size of which decreases towards the rear end of the body.

Below the mouth is the buccal capsule with an elongated shape, which turns into a muscular and then glandular pharynx. In our material the length of both pharynxes was quite great in both sexes, much higher than the values given in other works (Table 1). The end of the pharynx is located roughly in the middle of the body and also signifies its widest point.

Male. Below the glandular pharynx is located a nucleus with a poorly marked outline. At the distal end of the body

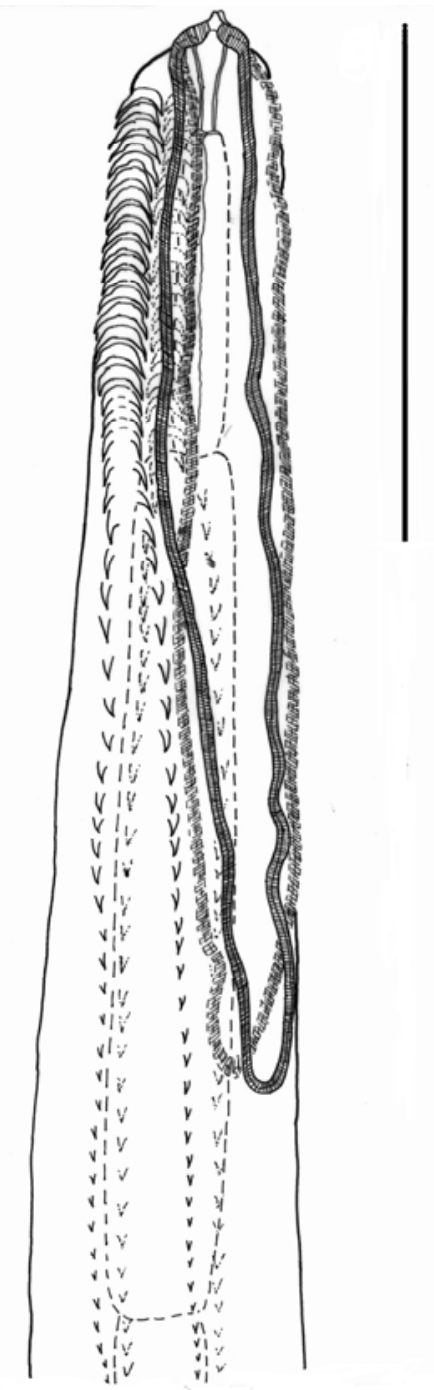

Fig. 1. Anterior end of male and female Echinuria hypognatha Wehr, 1937. Scale-bar $=0.5 \mathrm{~mm}$. two spicules are located, significantly different in size and shape (Fig. 2). The small spicule is short and its length is $1 / 3$ of the large spicule. The proximal part is broad with rough edges and gradually tapering. The spicule is curved in the shape of the letter "J", with a characteristic "head" in front and three branched ends at the distal part. The tail of the parasite is curved to the ventral side, equipped with wings and precloacal and postcloacal papillae. Due to the poor visibility of the papillae on the microslide, their numbers have not been determined.

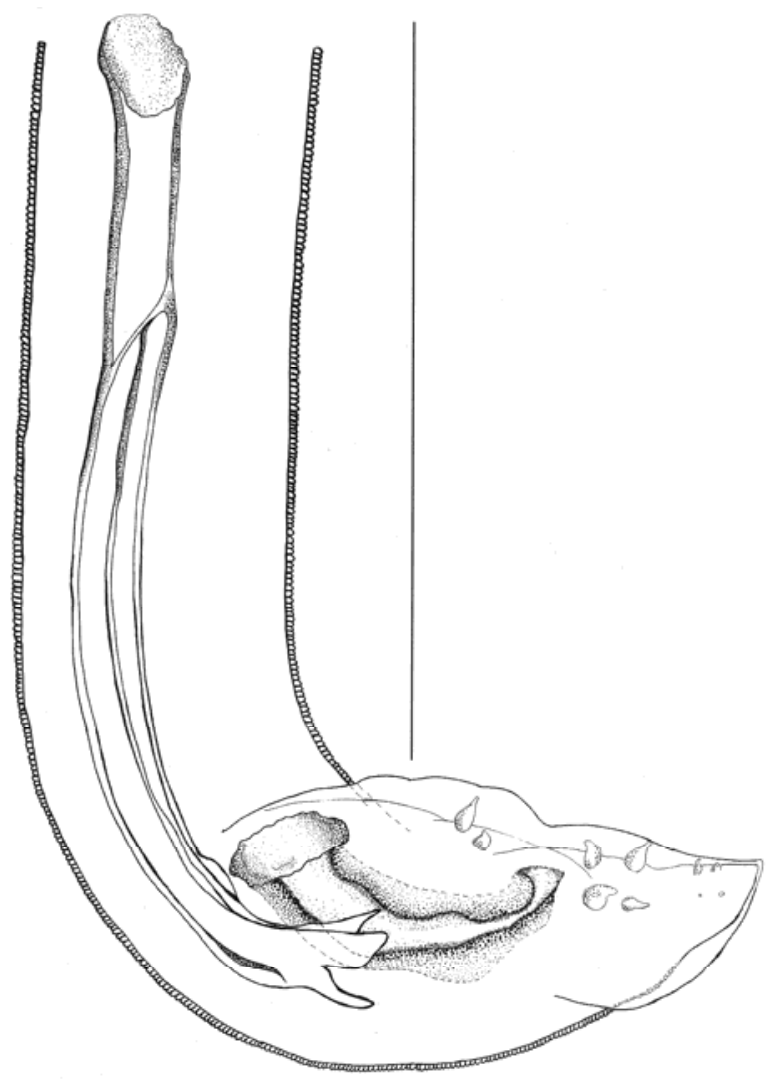

Fig. 2. Posterior end of male Echinuria hypognatha Wehr, 1937. Scale-bar $=0.5 \mathrm{~mm}$

Female. As in the males, the reproductive organs begin near the end of the glandular pharynx, with a single ovary with an average length of $1666.7 \mu \mathrm{m}$. The ovary ends in the uterus; a narrow slit - vulva leads to the uterus, with an average length $97.7 \mu \mathrm{m}$. The uterus is relatively short and monopolar. Its shape resembles a small, laterally laid bag with a thick knot. The length of the uterus ranges from 165 $\mu \mathrm{m}$ to $200 \mu \mathrm{m}$. During the study, the distance from the vulva to the posterior end of the body was relatively large. The presence of eggs was reported in the reproductive organs of only two examined females. The average length of an egg was $38.7 \mu \mathrm{m}$ and the width $21.6 \mu \mathrm{m}$. The tail is straight, conical and bluntly ended (Fig. 3).

The aforementioned characteristics of the parasite remain in line with the description of Wehr from 1937 and Ryzhikov (In: Skryabin et al. 1965). However, a few differences were found in the anatomy of certain structures. Firstly, in males there was no membrane surrounding the three- 


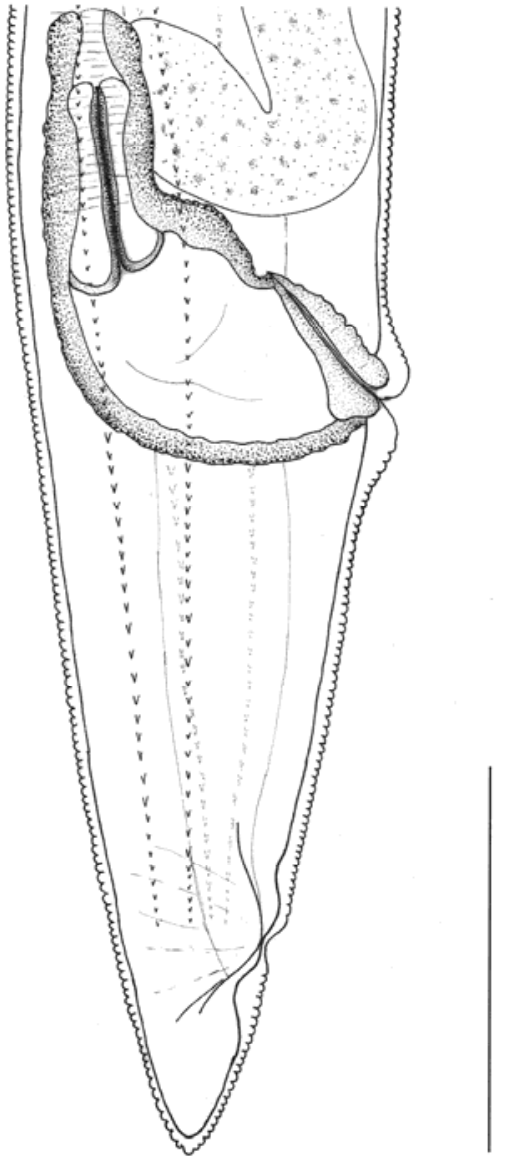

Fig. 3. Posterior end of female Echinuria hypognatha Wehr, 1937. Scale-bar $=0.5 \mathrm{~mm}$

branched end of the longer spicule, and differences in the number of pre-and postcloacal glands as mentioned by Ryzhikov (in: Skryabin et al. 1965). Furthermore, in this material only a few females were sexually mature and had eggs.

\section{Ecology}

Among 13333 nematodes isolated from the digestive tracts of the examined birds, $2804(21.0 \%)$ belonged to the genus Echinuria, including as many as 1864 (66.5\%) E. hypognatha, and the remainder were identified as $E$. uncinata (Rudolph, 1819). Although the habitat of all the Echinuria parasites is the glandular stomach, E. hypognatha nests deep in the pores of the epithelial tissue that lines the organ from the inside, while E. uncinata formed distinct nodules on the wall.

The parasite was found in five species of ducks wintering on the southern coast of the Baltic Sea (long-tailed duck, smew, velvet scoter and common scoter), and also in the tufted duck (wintering in the Pomeranian Bay). The analysis of environmental indicators of the parasite population (Table 2) shows that E. hypognatha is a parasite typical for Melanitta ducks (velvet scoter and tufted duck), since the vast majority of parasites $(98.7 \%)$ were found in ducks from this genus. Similarly other indicators of occurrence, such as intensity and relative density, reached the highest rates in those birds. The parasite was also found in one of the examined smew (Mergellus albellus), but it is difficult to conclude that the helminth is dominant in this host. The presence of one parasite in one of the examined 236 tufted ducks shows that for this species E. hypognatha is a nonspecific parasite. All of the aforementioned host species inhabit areas of Eastern Siberia, therefore it must be assumed that the parasite is brought to Europe by migrating birds and does not finish its life cycle in Europe.

\section{References}

Baruš, V., Sergeeva, T. P., Sonin, M. D., Ryzhikov, K. M. (1978): Helminth of Fish-Eating Birds of the Palaearctic Region I Nematoda. Moskwa/Praga, Academia Praha, 318 pp.

CARreno, R. A. (2008): Dispharynx, Echinuria and Streptocara. In: AtKinson, T. C., ThOMAS, N. C., Hunter, D. B. (Eds). Parasitic Diseases of Wild Birds. Iowa, USA: Wiley-Blackwell, pp. 326 - 342

KAVETSKA, K. M. (2006): Biological and ecological background of nematode fauna structure formation in the alimentary tracts of wild Anatinae ducks in north-western Poland. Habilitation thesis, Poland, Szczecin: Academy of Agriculture (In Polish)

Table 2. Ecology characteristic of E. hypognatha found in the Anatinae from north-western Poland

\begin{tabular}{lrrrrrrrr}
\hline & & \multicolumn{2}{c}{ Prevalence } & \multicolumn{2}{c}{ Intensity } & Relative & Dominance \\
\cline { 3 - 7 } Host & Frequency & $\mathrm{n}$ & $\%$ & range & mean & density & \\
\hline Clangula hyemalis, $\mathrm{n}=112$ & 21 & 5 & 4.46 & $1-8$ & 4.2 & 0.19 & 0.008 \\
Melanitta nigra, $\mathrm{n}=108$ & 1150 & 10 & 9.26 & $1-744$ & 115.0 & 10.65 & 0.986 \\
M. fusca, $\mathrm{n}=48$ & 690 & 8 & 16.67 & $2-520$ & 86.3 & 14.38 & 2.396 \\
Mergellus albellus, $\mathrm{n}=1$ & 2 & 1 & 100.00 & 2 & 2.0 & 2.00 & 2.000 \\
Aythya fuligula, $\mathrm{n}=236$ & 1 & 1 & 0.42 & 1 & 1.0 & 0.00 & 0.000 \\
\hline Total, $\mathrm{n}=505$ & 1864 & 25 & 4.95 & $1-744$ & 74.56 & 3.69 & 0.1827 \\
\hline
\end{tabular}


KAVETSKA, K. M. (2008): Nematofauna of duck of the genus Melanitta (Mergini, Anseriformes) from the south Baltic Sea. Wiad. Parazytol., 54(2): 155 - 157

POJMAŃSKA, T. (1993): The review of ecological terms used in modern parasitology. Wiad. Parazytol., 39(3): 285 - 297

PojmańsKa, T., NieWIAdOMSKA, K., OKulewicz A. (2007): Parasitic helminths in Poland Species, Hosts, Blans Pages. Warszawa, Poland, Polish Parasitological Society, 360 pp. (In Polish)
Skryabin, K. I., Sobolev A. A., IVAShKin V. M. (1965): Spiruride of animals and man, and the associated diseases. Part III, Acuariidae. Osnovy Nematologii. Volume 14, The Academy of Sciences, the Soviet Union, Moscow, 572 pp. (In Russian)

SMOGORZEWSKA, L. A. (1990): The fauna of Ukraine. Nematodes. Acuarioidea. The Academy of Sciences, Ukrainian Republic in the Soviet Union, Kiev, Naukowa Dumka, 188 pp. (In Russian)

ACCEPTED DECEMBER 15, 2011 